\title{
Progressive Disease in Neuroblastoma
}

National Cancer Institute

\section{Source}

National Cancer Institute. Progressive Disease in Neuroblastoma. NCI Thesaurus. Code C140671.

Any component (i.e., soft tissue, bone, and bone marrow disease) with progressive disease. ( Clin Oncol 35: 2580-2587, 2017) 